\title{
SINOATRIAL NODE ARTERY COMMUNICATED WITH CUT-OFF LEFT ANTERIOR DESCENDING ARTERY
}

\author{
TOTAL TIKALI SOL ÖN INEN ARTERIN SINOATRIYAL NOD ARTER ILE DOLUŞU
}

Balıkesir Üniversitesi Tıp Fakültesi
Kardiyoloji AD
Yazışma Adresi:
Turgay IŞıK
Balıkesir Üniversitesi Tıp Fakültesi
Kardiyoloji Anabilim Dalı
Çağış 10145 Balıkesir - Türkiye
E posta: isikturgay@yahoo.com

Kabul Tarihi: 05 Haziran 2012

Balıkesir Sağlık Bilimleri Dergisi

ISSN: 2146-9601

e-ISSN: 2147-2238

bsbd@balikesir.edu.tr www.bau-sbdergisi.com

\section{Turgay IŞIK Erkan AYHAN}

The artery that supplies the sinoatrial node (SAN) artery was a branch of either the right or left coronary artery. Most frequently (in 63\% of case), the SAN node artery was the first anterior atrial branch of right coronary artery. A 79 year old male was presented to our cardiology department with gradually progressive typical chest pain for the preceding one year. He had no history coronary artery disease. On physical examination, his arterial blood pressure was seen $135 / 75 \mathrm{mmHg}$ and the electrocardiogram revealed sinus rhythm and heart rate was $75 \mathrm{bpm} /$ regular. Cardiac auscultation showed 2/6 grade systolo-diastolic murmur and the rest of physical examination including respiratory sounds was unremarkable.

Transthoracic echocardiography showed hypokinetic walls in the left ventricular apex and interventricular septum in mid and apical sections, mild mitral and aortic regurgitation with a calculated ejection fraction of $38 \%$ by using modified Simpson's rule. Coronary angiography showed right coronary artery was high grade stenosis from the after SAN artery and circumflex artery had critical lesion from the proximal segment. The left coronary artery was totally occluded from the midportion and was supplied retrograde fashion by the SAN artery (Figure $1 \mathrm{~A}$ and $1 \mathrm{~B}$ ). The patient was referred to the cardiovascular surgery department for coronary artery bypass operation. However, he refused the surgical operation or percutaneous coronary intervention. He was discharged on medical treatment.

Figure 1A. Chronic total left anterior descending (LAD) lesion. (Cx: Circumflex artery)

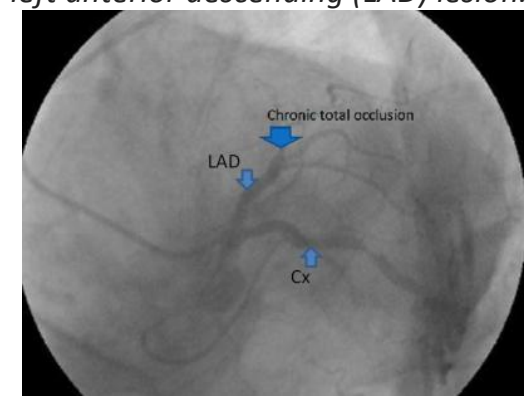

Figure1B. Sinoatrial node artery (SAN) communicated with cut-off left anterior descending artery (LAD). (RCA: Right coronary artery)

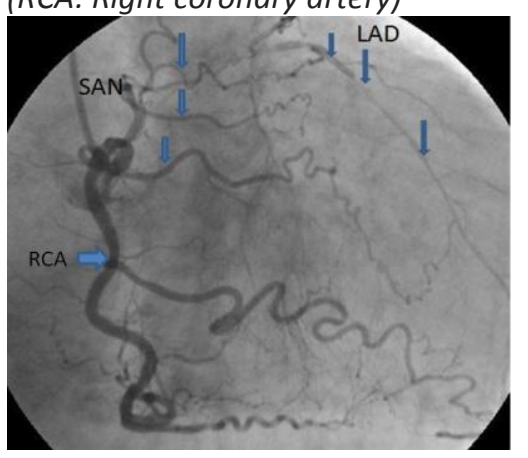


